\title{
MECHANICAL ACTIVATION OF FLY ASH: PHYSICAL, MINERALOGICAL AND MORPHOLOGICAL CHARACTERIZATION OF GROUND FLY ASHES
}

\author{
Sedef DIKKMEN" ${ }^{1}$, Zafer DİKMEN¹, Gülgün YILMAZ², Seyhan FIRAT ${ }^{3}$ \\ ${ }^{1}$ Department of Physics, Science Faculty, Eskişehir Technical University, Eskişehir, Turkey \\ ${ }^{2}$ Department of Construction Division, Program in Building Inspection, Eskişehir Technical University, Eskişehir, Turkey \\ ${ }^{3}$ Department of Civil Engineering, Technology Faculty, Gazi University, Ankara, Turkey
}

\begin{abstract}
In this study, physical, mineralogical and morphological characteristics of mechanically treated fly ashes are investigated. The compositional analysis of the raw fly ash was determined using X-ray fluorescence (XRF) technique. The XRD patterns reveal that the main phase quartz along with mullite and anhydrite. The raw fly ash was also wet ground using a laboratory mill, for several different times (from 2 to 16 hours) in order to examine how the grinding increases the activity of the fly ash. The ground fly ash was characterized for (i) particle size distribution: laser diffraction method, (ii) specific surface area: BETmethod, (iii) crystalline structure: X-ray diffractometer, and (iv) morphology of particles: scanning electron microscope. According to physical characterization, fineness increasing of samples with grinding time was observed, but loss of effectiveness occurred for grinding time longer than 12 hours. In addition, the unmilled fly ash showed lower specific surface area, due to the presence of cenospheres in the original fly ash. Only a little change in crystalline structure of fly ashes was observed when grinding and there were changes in the area and height of each diffraction peak.
\end{abstract}

Keywords: Ground fly ash, Particle size distribution, Specific surface area, Microstructure, XRD

\section{INTRODUCTION}

Fly ash is a silica-aluminate rich pozzolanic generated as by-product during the combustion of lignite or sub-bituminous coals [1]. Unfortunately, thermal power plants are still using pulverized coal heavily for electricity generation all over the world $[2,3]$. Therefore, storage of fly ash in large landfill is significant problem due to space constraints, and the impact on surrounding area is also well known. Fly ash particles that are small enough to escape from the emission control devices are easily moved by air or wind and therefore air pollution occurs threat to both public health and the environment [4]. Since the 1980s, researchers have been focused on the waste fly ash utilization especially in geotechnical applications as a supplementary cementing material (SCM), as a road sub-base and soft subgrade stabilizing agent or soil amendment, mining application, etc. Recycling of fly ash can be a good alternative to disposal and can also provide significant economic and environmental benefits. Although a portion of the derived fly ash is used as fillers in brick manufacturing, ceramic industry and road or dam construction, a significant amount is still accumulated in vast areas with serious environmental consequences [5]. The potential applications are not sufficient for the utilization of the whole fly ash produced. Attempts for the use of fly ash should be on a large scale, so that there is an effective way to prevent such pollution. Therefore, characterization of fly ash in a very complex structure (chemical composition, loss on ignition, morphology, mineralogy, glass content, fineness, surface chemistry, reactivity, etc.) is important in the development of its various applications [5]. Fly ash is obtained by burning the coal at $1200-1700{ }^{\circ} \mathrm{C}$, which contains various inorganic and organic matters [6]. When it is burned, the organic constituents (non-crystalline matters, carbon etc.) in the coal are burned out. However, the inorganics composed of char materials and minerals such as clay, quartz and feldspar remain suspended in the flue gases. Some of the suspended particles, which are not completely

*Corresponding Author: sdikmen@eskisehir.edu.tr

Received: 09.10.2019 Published: 16.12.2019 
combusted minerals, agglomerate and become rough particles [7].The mean phase-mineral composition of fly ash includes mullite $\left(3 \mathrm{Al}_{2} \mathrm{O}_{3} \cdot 2 \mathrm{SiO}_{2}\right)$, quartz $\left(\mathrm{SiO}_{2}\right)$, magnetite $\left(\mathrm{Fe}_{3} \mathrm{O}_{4}\right)$, anhydrite $\left(\mathrm{CaSO}_{4}\right)$, anorthite $\left(\mathrm{CaAl}_{2} \mathrm{Si}_{2} \mathrm{O}_{8}\right)$ and lime $(\mathrm{CaO})$ and depends on the geological factors related to the formation and deposition of coal, which are known as minerals [8].

The physicochemical properties of fly ash belong to the type of coal and combustion conditions. The fly ash comprises $\mathrm{Si}$, $\mathrm{Al}$ and $\mathrm{Fe}$ (in both crystalline and amorphous form) as a major element and together with minor elements of $\mathrm{Ca}, \mathrm{Na}, \mathrm{K}$ and $\mathrm{Ti}$, which are compositionally similar to zeolites a valuable material used as adsorbent or catalyst for environmental and industrial applications such as wastewater treatment and soil remediation [9]. Fly ash is the hollow aluminosilicate microsphere with size $0.2-200 \mu \mathrm{m}$ and shell thickness about $5-10 \%$ of its diameter. Some microspheres are hallowing (cenospheres), while others (plerospheres) are filled with smaller amorphous particles are crystals [10]. Fly ash has a low bulk density $(0.9-1.3 \mathrm{gm} / \mathrm{cc})$, hydrophillic and high specific surface area. In general, smaller particles tend to become more reactive for two causes. Firstly, smaller particles have larger surface areas making a large proportion of the particle present to attack by hydroxides. Secondly, it perhaps more important, smaller particles cool rapid upon exiting from combustor, resulting in a more complex, therefore, reactive structure [8]. One of the most important uses of fly ash is as cement that used instead of Portland cement in concrete due to its cementitious and pozzolanic properties. The factors affecting pozzolanic reactivity are as follows: the percentage of reactive silica is a part of the fly ash that reacts with the alkali solution, the composition of the glassy phases, percentage of $\mathrm{SiO}_{2}+\mathrm{Al}_{2} \mathrm{O}_{3}+\mathrm{Fe}_{2} \mathrm{O}_{3}$, particle size distribution, specific surface area and the amount of unburnt substance. If fly ash contains a higher amount of reactive silica, with higher specific surface area and lower particle size distribution, the mechanical strength of the fly ash mortar would reach higher values. In recent years, some researchers to improve their pozzolanic reactivity, various methods have been investigated different methods [11-13], such as activation [14], alkali activation [15], and sulfate activation [16]. However, this kind of treatment methods is expensive and poor durability. Therefore, in order to make better utilization of fly ash, it is refined by mechanical activation. It has been found that mechanical activation, is not only reduced the crystal defects of a material during the grinding; but also improves the reactivity of materials like granulated blast furnace slag, fly ash and metakaolin that insufficiently interact with other substances [17]. Marjanovica et al. (2015) [18] expressed that mechanical activation provides an opportunity to alter surface reactivity of fly ash without changing the chemical composition of material. Such mechanical activation not only improves degree of fineness but also involves breaking of bonds, dispersion of particles, generation and migration of chemical components in the bulk, thus results in increased surface roughness and specific surface area [19]. Rajak et al. [20] studied dry grinding of Class-F fly ash was milled using the planetary ball mill to produce mechanically activated particles. The specific surface area of milled fly ash was increased from $7.31 \mathrm{~m}^{2} \mathrm{~g}^{-1}$ to $28.08 \mathrm{~m}^{2} \mathrm{~g}^{-1}$ resulting fine grinding, whereas crystallinity of fly ash and crystallite size of quartz in glass phase was decreased by $26.12 \%$ and $40.1 \%$, respectively. Chindaprasirt et al. (2004) [21] pointed out that finer fly ash with high surface area was more reactive and thus resulted in the increase in strength. The finer fly ash also required less water owing to its spherical shape and smooth surface. Its filling of the cavities helped increase the compressive strength of the mortar. Lee et al [22] stated that a larger degree of pozzolanic reaction of the fine fly ash is a consequence of calcium hydroxide of the fine fly ash cement paste was greater than that of the rough fly ash cement paste. The development of the strength also depends on the glass content of the fly ash.

Coal (i.e. lignite, bituminous and sub-bituminous coals) is the most important natural energy source available in Turkey and used as fuel for thermal power plants. More than $30 \%$ of the electricity is generated by crushed coal combustion, with resulting in significant amount of fly ash, which also causes environmental impact [3]. According to the statistics reports, total solid waste produced in thermal power plants (bottom ash, fly ash, slag, gypsum etc.) was 19.5 million tons in 2016 . While approximately $83 \%$ of these wastes was disposed and about $16 \%$ was sent to mines and quarries and only $3 \%$ was 
recycled [23] Therefore, assuming that $80 \%$ of the mineral waste of fly ash, the very high disposed portion, dumped into landfill and leads to environmental damage. Studies for the utilization of fly ash in Turkey are necessary to reduce environmental problems and avoid economic loss caused by the disposal of fly ash. To improve fly ash properties, particularly the particle size distribution, various processing methods have been developed. The most frequently used procedures in practice are classification and crushing by grinding.

The aim of the present paper is to investigate the physical, structural and morphological characterization of fly ash from Çayırhan (Ankara). It has been subjected to mechanical activation under wet conditions. Mechanical activation is persuaded using a planetary mill since this is a type of high-intensity mill that is commonly used for mechanical activation. In order to determine the fine grinding time of fly ash, a serious of experimental studies were carried out by selecting five grinding periods: 2, 4, 8, 12 and 16 hours, respectively. The ground fly ash was characterized for particle size distribution, specific surface area, crystalline structure and morphology of particles.

\section{MATERIALS AND METHODS}

\subsection{Characterization of Raw Material}

The raw material was Class-C fly ash supplied by the Çayırhan Thermal Power Plant in Ankara. It was classified according to the ASTM C-618 [24] standards requirement for the fly ash in terms of its chemical composition, particle size and particle shape.

Table 1. Chemical composition and some physical properties of fly ash used for the study (as received)

\begin{tabular}{|c|c|}
\hline Chemical Composition & wt.\% \\
\hline $\mathrm{CaO}$ & 19.27 \\
\hline $\mathrm{SiO}_{2}$ & 45.37 \\
\hline $\mathrm{Al}_{2} \mathrm{O}_{3}$ & 10.96 \\
\hline $\mathrm{Fe}_{2} \mathrm{O}_{3}$ & 9.36 \\
\hline $\mathrm{MgO}$ & 4.49 \\
\hline $\mathrm{K}_{2} \mathrm{O}$ & 2.83 \\
\hline $\mathrm{Na}_{2} \mathrm{O}$ & 1.33 \\
\hline $\mathrm{TiO}_{2}$ & 0.68 \\
\hline $\mathrm{P}_{2} \mathrm{O}_{5}$ & 0.59 \\
\hline $\mathrm{MnO}$ & 0.14 \\
\hline $\mathrm{SO}_{3}$ & 4.35 \\
\hline Loss & 0.63 \\
\hline \multicolumn{2}{|c|}{ Physical Properties $[25,26]^{*}$} \\
\hline *Liquid limit, $\%$ & 21.80 \\
\hline *Plastic limit, $\%$ & 17.50 \\
\hline *Plasticity index, \% & 4.30 \\
\hline *Specific gravity, g/cc & 2.27 \\
\hline $\mathrm{SSA}_{\mathrm{BET}}, \mathrm{m}^{2} / \mathrm{g}$ & 2.06 \\
\hline \multicolumn{2}{|c|}{ Particle size $(\mu \mathrm{m})$} \\
\hline $\mathrm{D}(10)$ & 0.603 \\
\hline $\mathrm{D}(50)$ & 9.350 \\
\hline $\mathrm{D}(90)$ & 43.400 \\
\hline
\end{tabular}


The X-ray fluorescence (XRF, Rigaku ZSX Primus) was used to find chemical composition, the laser diffraction method (Mastersizer 3000) was applied to realize particle size distribution, surface area analyser (Quantachrome Nova 2200) was performed to analyse specific surface area (SSA ray diffraction (XRD, Rigaku Rint 2000) was used to obtain mineralogical analysis and FE-SEM (CarlZeiss Evo 50 EP) was employed to surface morphological analysis of fly ash sample. Liquid limit, plastic limit, plasticity index and specific gravity of fly ash determined in a previous study [25, 26]. The results obtained from these analyses are given in Table 1.

Figure 1 shows the $\mathrm{X}$-ray diffraction pattern of the fly ash sample. The fly ash sample comprised the mineral phases such as: quartz $\left(\mathrm{SiO}_{2}\right)$, anhydrite $\left(\mathrm{CaSO}_{4}\right)$, mullite $\left(\mathrm{Al}_{6} \mathrm{Si}_{2} \mathrm{O}_{13}\right)$, anorthite $\left(\mathrm{CaAl}_{2} \mathrm{Si}_{2} \mathrm{O}_{8}\right)$ and hematite $\left(\mathrm{Fe}_{2} \mathrm{O}_{3}\right)$.

Figure 2 is a SEM micrograph of the fly ash sample showing predominantly spherically shaped powder particles, a typical particle morphology for fly ash powders.

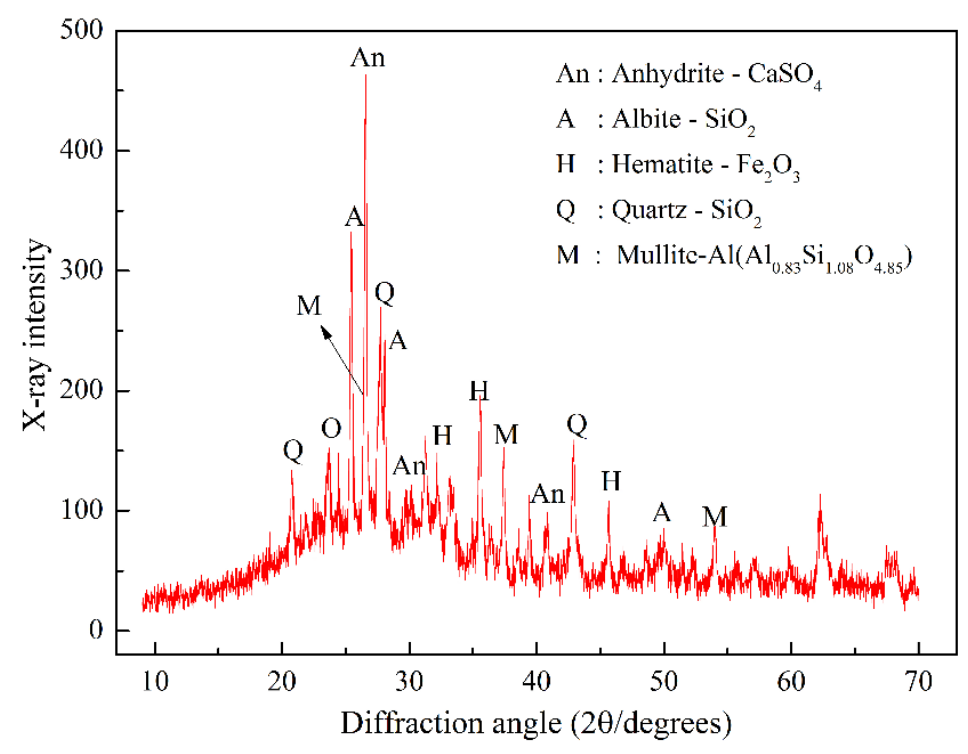

Figure 1. XRD analysis of fly ash (as-received)

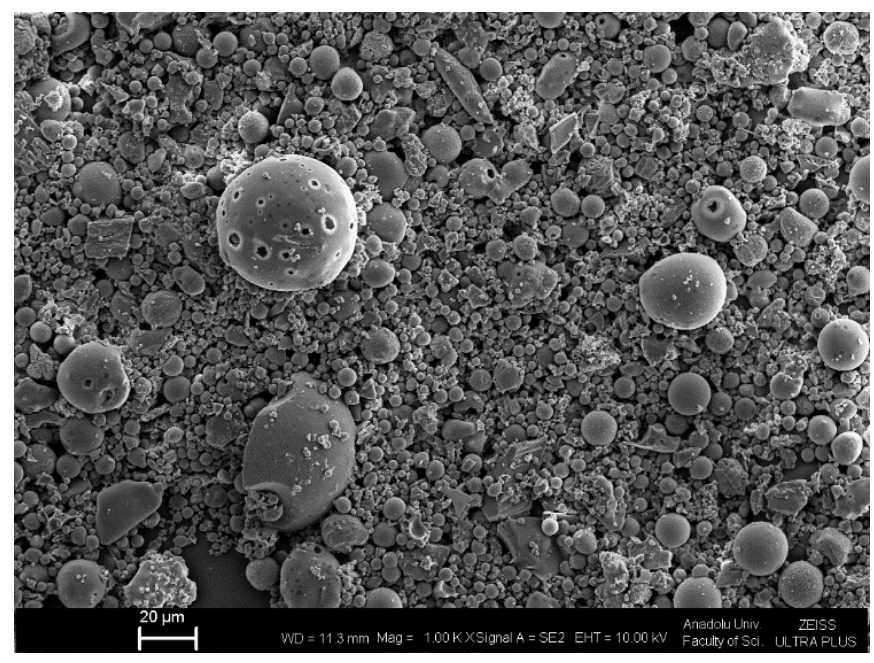

Figure 2. SEM image of fly ash (as-received) 


\subsection{Grinding of Fly Ash}

The wet grinding experiment of fly ash was carried out by using laboratory ball mill (FRITCHPulverisette 6). The type of the grinding pot is zirconium oxide and the grinding media is composed by 40 zirconium oxide balls $(\Phi 10 \mathrm{~mm})$ and $50 \mathrm{ml}$ solid $/ 100 \mathrm{ml}$ distilled water. The weight of materials for each grinding experiment was 76.73 grams. The fine powders were oven dried at $100{ }^{\circ} \mathrm{C}$ and kept in plastic bottle for later use.

\subsection{Test Methods for Ground Fly Ash}

The particle size distributions of 2 to 16 hours ground samples were measured by laser diffraction method in isopropyl alcohol dispersions using Malvern Mastersizer 3000 and deduced by the Mie optical model as:

$$
m=n-i k
$$

where $m$ is the complex refractive index; $n$ is the real component and $k$ is the imaginary component [27]. The real component $n$ was determined by the normalized mass fraction of $\mathrm{Al}_{2} \mathrm{O}_{3}$ and $\mathrm{SiO}_{2}$ of the specific fly ash (Table 1). The imaginary component $\mathrm{k}$ and the refractive index of dispersant are 0.1 and 1.380 , respectively.

The specific surface area $\left(\mathrm{SSA}_{\mathrm{BET}}\right)$ was measured by the nitrogen adsorption isotherms (Quantachorome Instruments, NOVA 2200). The ground fly ash samples were degassed at $80^{\circ} \mathrm{C}$ for $12 \mathrm{~h}$. After degassing, the sample was measured on a nine-points isotherm in a relative pressure $\mathrm{P} / \mathrm{P}_{0}$ range of $0.05-0.30$. Based on the BET method, the adsorption isotherm was used to determine the SSA

X-ray diffraction is a tool used to find the crystalline phases of raw and ground samples. The XRD analysis of fly ash and ball milled particle was performed to identify the crystalline phase with a range of the Bragg angle $2 \theta\left(5^{\circ} \leq 2 \theta \leq 70^{\circ}\right)$ using $\mathrm{CuK}_{\alpha}$ radiation at $40 \mathrm{kV}$ accelerating voltage and $15 \mathrm{~mA}$ current with $0.02 \%$ sec scanning speed.

Particles morphology of ground fly ash powder were examined by FE-SEM (at $8 \mathrm{kV}$ ) to observe the changes in microstructure properties of all grounded samples. The samples were held on an aluminum sample holder with adhesive tape. Later, they were coated with Au-Pd to minimize any charge buildup.

\section{RESULTS}

\subsection{Particle Size and Specific Surface Area of Grounded Fly Ash}

Fly ash has a broad size distribution, with diameters spanning more than three orders of magnitude. Therefore, it is difficult to measure the dispersion of the size distribution. As seen from Table 2 and Fig. 3 , that median diameter $\mathrm{D}(50)$ of fly ash decreased from $9.35 \mu \mathrm{m}$ to $1.21 \mu \mathrm{m}$ by grinding, decreasing by $8.14 \mu \mathrm{m}$. It indicates the grinding treatment plays a significant role on particle size distribution of fly ash particles, but such size was increased again upon longer grinding time (as $16 \mathrm{~h}$ ). These results show good agreement with SEM images.

As seen from Table 2 and Figure 3, that median diameter $\mathrm{D}(50)$ of fly ash decreased from $9.35 \mu \mathrm{m}$ to $1.21 \mu \mathrm{m}$ by grinding, decreasing by $8.14 \mu \mathrm{m}$. It indicates the grinding treatment plays a significant role on particle size distribution of fly ash particles, but such size was increased again upon longer grinding time (as $16 \mathrm{~h}$ ). These results show good agreement with SEM images. 


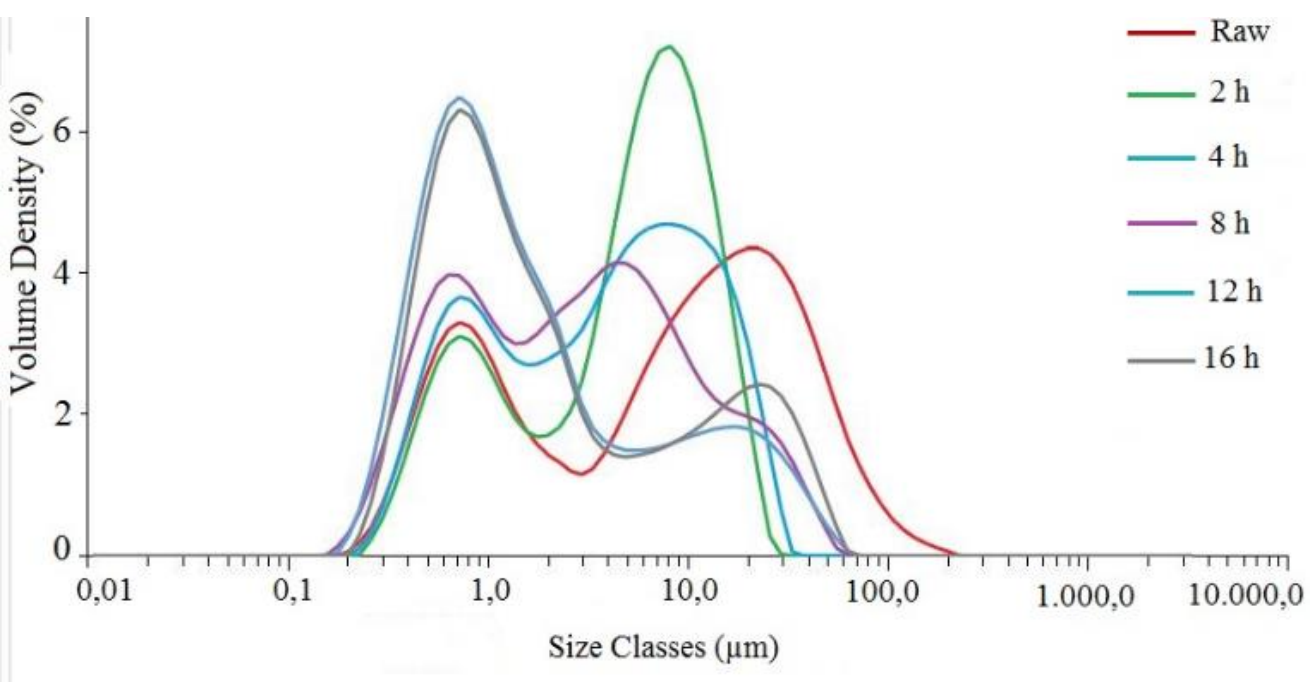

Figure 3. The variation of the size distribution of fly ash particles during ball grinding at 2, 4, 8, 12 and 16 hours determined by laser diffraction technique.

Grinding process leads to the generation of larger specific surface area, but the agglomeration phenomena (for mechanical-chemical reaction during grinding) that generally associated with long duration grinding, inversely affects the pozzolanic property. The increase in grinding time results in particles size reduction, but the rate of decrease of particle sizes is not proportionally related with grinding time. Various factors such as initial particle size, softness and carbon content affect the performance of grinding [28].

Table 2. Changes in particle size distribution and SSABET during ball grinding at 2, 4, 8, 12 and 16 hours

\begin{tabular}{ccccc}
\hline $\begin{array}{l}\text { Grinding } \\
\text { Time }\end{array}$ & $\begin{array}{c}\mathbf{D}(\mathbf{1 0}) \\
(\boldsymbol{\mu m})\end{array}$ & $\begin{array}{c}\mathbf{D}(\mathbf{5 0}) \\
(\boldsymbol{\mu m})\end{array}$ & $\begin{array}{c}\mathbf{D}(\mathbf{9 0}) \\
(\boldsymbol{\mu m})\end{array}$ & $\begin{array}{c}\text { SSABET } \\
\left(\mathbf{g} / \mathbf{m}^{2}\right)\end{array}$ \\
\hline Raw & 0.603 & 9.35 & 43.40 & 0.183 \\
\hline $2 \mathrm{~h}$ & 0.650 & 5.51 & 13.90 & 0.218 \\
\hline $4 \mathrm{~h}$ & 0.592 & 4.05 & 15.90 & 0.252 \\
\hline $8 \mathrm{~h}$ & 0.472 & 2.75 & 17.30 & 0.194 \\
\hline $12 \mathrm{~h}$ & 0.423 & 1.21 & 16.50 & 0.328 \\
\hline $16 \mathrm{~h}$ & 0.465 & 1.38 & 22.70 & 0.231 \\
\hline
\end{tabular}

The specific surface areas (SSA $\mathrm{BET}_{\text {) }}$ of samples are given in Table 2. The SSA $\mathrm{BET}_{\mathrm{BET}}$ of fly ash particles increased after grinding treatment, whereas the value of $\mathrm{SSA}_{\mathrm{BET}}$ did not linearly correlated with grinding time due to the agglomeration among particles. The results are consistent with the literature $[29,30]$.

\subsection{X-ray Diffraction of Grounded Fly Ash}

The XRD patterns of fly ash and ball milled particles at different times were given in Figure 4. It has been found that peaks have not changed before and after the grinding of the fly ash. No significant peaks were observed in the beginning $\left(5^{\circ}\right.$ to $\left.10^{\circ}\right)$ and ending $\left(70^{\circ}\right.$ to $\left.80^{\circ}\right)$ of parts of the patterns. Therefore, these parts are not shown. The important finding here is that after the milling process, a new crystal phase does not appear in the fly ash. Therefore, it is clear that the mineral composition has not changed due to the grinding of the samples. However, significant variations in the width and height of the several peaks have been observed for some grinding times. The intensity of some peaks decreased with an 
increased grinding time from 4 to 12 hours. In the 4 and 8 hours grinding process, the intensity of the diffraction peaks belonging to the anhydrite was reduced, especially at $2 \theta=25.4^{0}$. Even for 12 and 16 hours of grinding, these peaks are almost diminished. This was also true for the pair of 8 and 12 hours grinding time, especially on their quartz and mullite phases. The results indicated that the grinding treatment resulted in the preferential orientation of crystal planes, and increased the corresponding amorphous like silica, hence leading the improved pozzolanic activity [31].

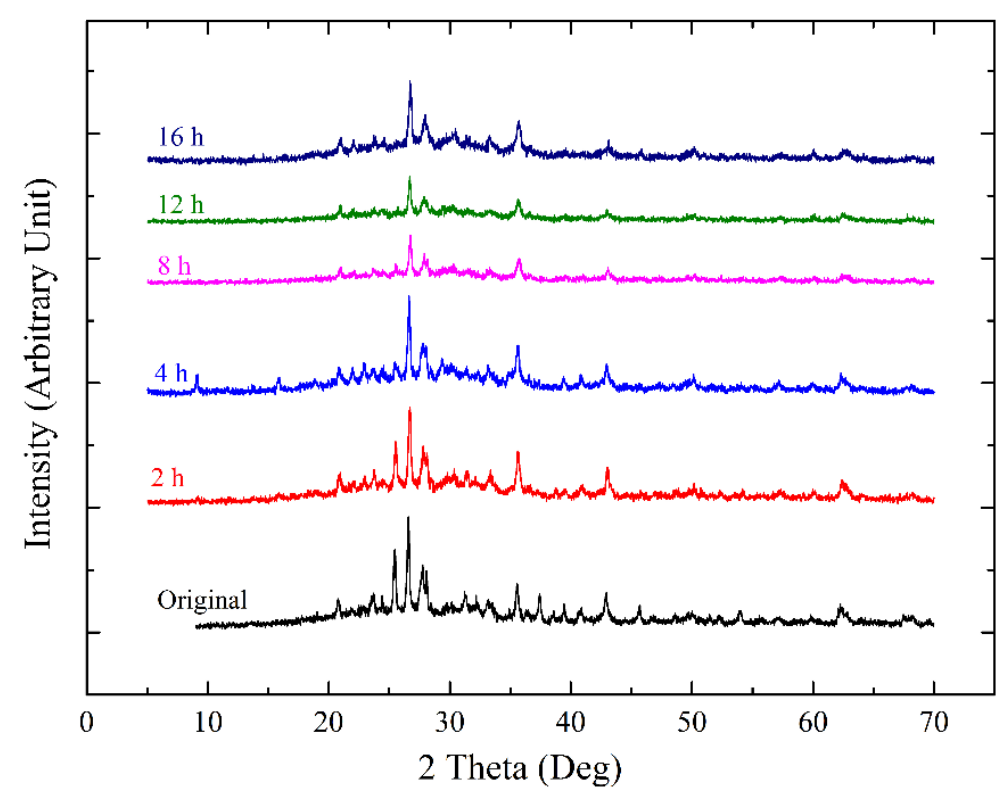

Figure 4. The XRD patterns of fly ash samples ground for 2, 4, 8, 12 and 16 hours in a planetary ball mill at $350 \mathrm{rpm}$.

\subsection{SEM Analysis of Grounded Fly Ash}

The SEM micrographs of raw and ground fly ash particles are shown as Figure 5 (a)-(e), which displays the morphology after grinding is significantly changed and particle size decreased as grinding time increased. The small particles of fly ash remain spherical state, but the most large particles of fly ash are crushed into small particles and they are no longer in the spherical state. It is apparent that the cracking of cenospheres and perospheres forms shell-shaped fragments and the other part shows the splintered and highly irregular shapes $[29,30,32,33]$. The shape of particles changed from spherical to nonspherical due to grinding and agglomeration, where it was also observed fine particle smaller than $3 \mu \mathrm{m}$ in agglomerates of 20-30 $\mu \mathrm{m}$, especially in Figure 5 (c). 


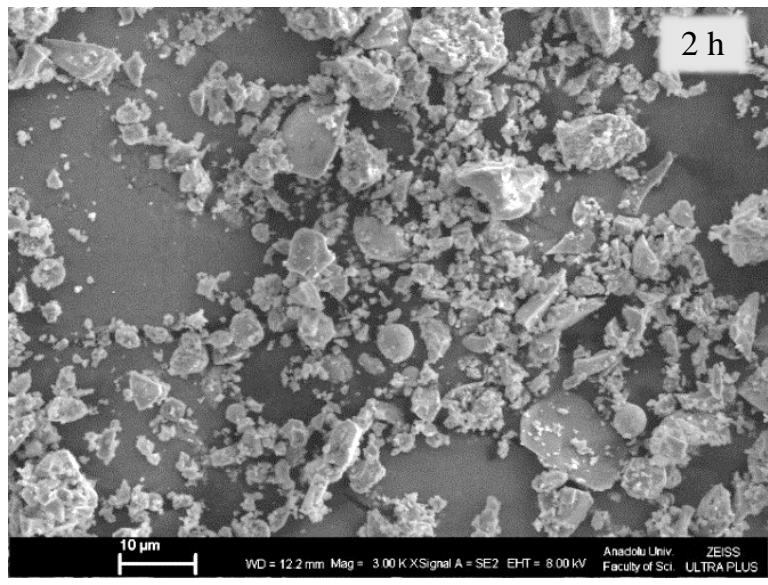

(a)

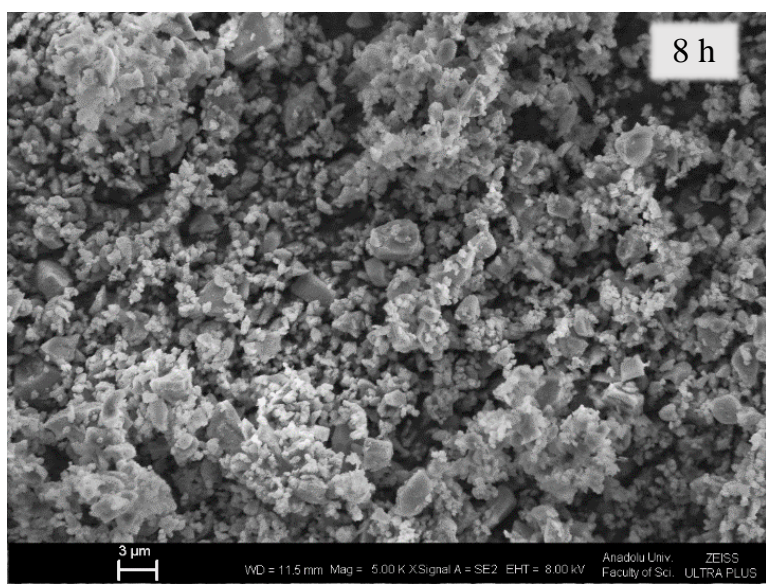

(c)

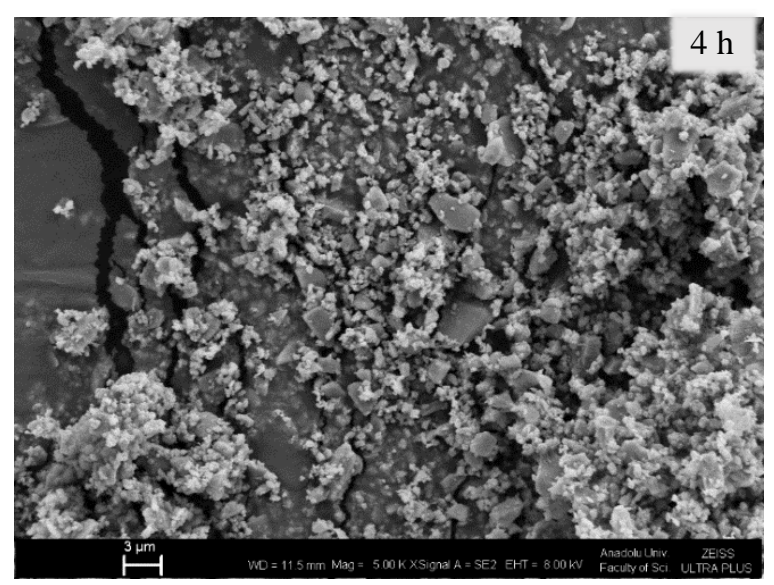

(b)

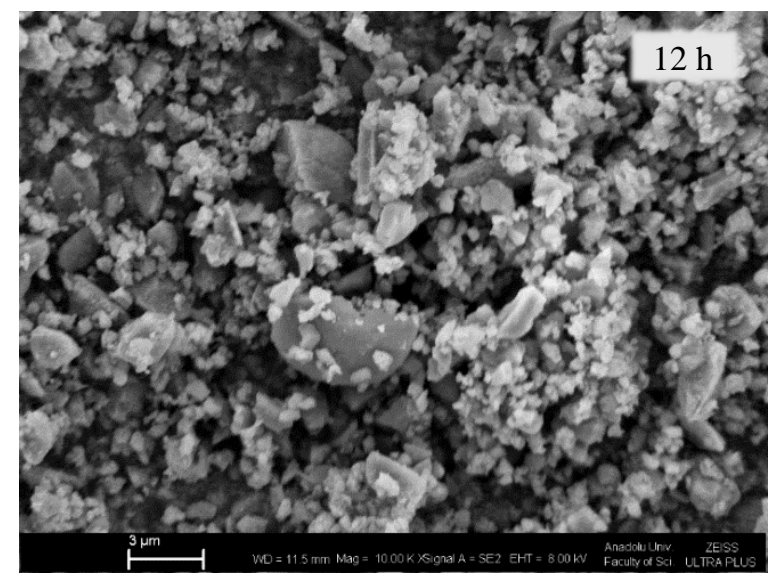

(d)

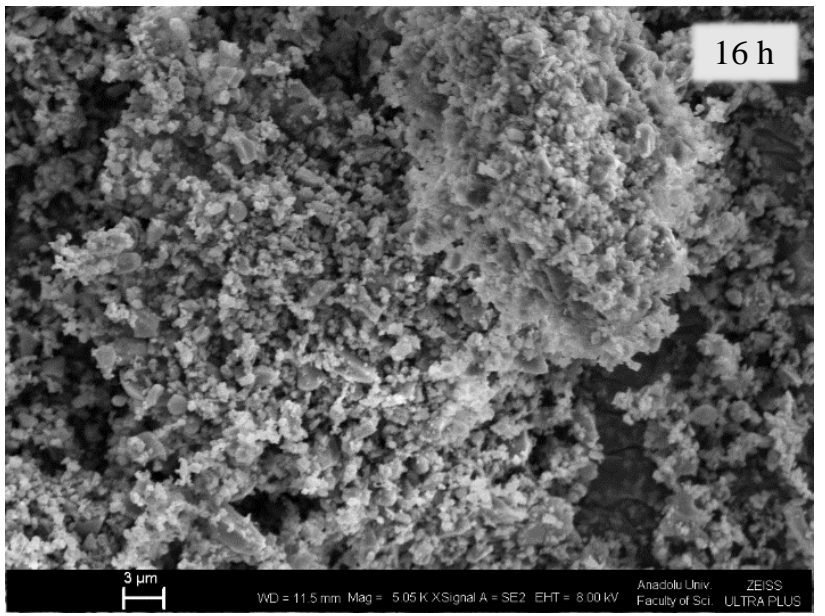

(e)

Figure 5. SEM micrographs of ground fly ash particles in five different times: (a) $2 \mathrm{~h}$, mag. $=3 \mathrm{KX}$, (b) $4 \mathrm{~h}, \mathrm{mag} .=5 \mathrm{KX}$, (c) $8 \mathrm{~h}$, mag. $=5 \mathrm{KX}$, (d) $12 \mathrm{~h}$, mag. $=10 \mathrm{KX}$, (e) $16 \mathrm{~h}$, mag. $=5 \mathrm{KX}$ 


\section{DISCUSSION}

- The fly ash shows a variation in their chemical and mineralogical composition depending on the nature of coal, conditions of combustion and type of emission control devices. The mineralogical composition of the ashes can vary even for a single coal deposit depending also on parameters like time of collection, i.e. night or day, winter or summer.

- The smallest median diameter $\mathrm{D}(50)$ value is belong to the ground fly ash for 12 hours sample.

- Increasing of specific surface area of fly ash particles is achieved when grinding due to crushing hollow particles, and inversely, bulk surface area of fly ashes decreased due to loss of optimum spherical shape morphology.

- Grinding of fly ashes mainly broken down coarse particles, yielding shell-shaped fragments (as Figure 5 (d)), from original cenospheres and plerospheres, and solid fragments with or without retaining partially original spherical shape.

- After grinding of fly ash, its mineralogical composition was unchanged. Before grinding of fly ashes presented typical peaks in the X-ray diffractogram corresponding to fly ash with high calcium content: quartz (Q), anhydrite (An), anorthite (A), hematite (He) and mullite (M) are present as major crystalline components. The results of XRD analysis indicated that there was no generation of the new crystal phase after grinding treatment, but there were changes in the area and height of some diffraction peak.

- The characterizations revealed the fine grinding of fly ash resulted in that not only the increase of their specific surface areas, but also the increase of crystallinity degree.

\section{CONCLUSION}

The effect of wet grinding on the physical properties, crystalline structural and surface morphological properties of fly ash are reported in this paper. In the mechanical activation, it is observed that particle size diminishes as activation time increases and changed the physical and mineralogical properties of particles, decrease particle size, increase specific surface area, induce crystal defects, and reduce the relative crystallinity during the grinding process. It can be said that, grinding process of fly ash provides particularly promising for the construction industry. There is a need to produce more data in order to explain the behaviour of the grinding process under different conditions, such as milling time, rotation rate, diameter of balls, and volume ratio of water to powder and level of filling of the bowl.

\section{ACKNOWLEDGEMENTS}

The authors are thankful to Mr. Orhan ÇETIN, from Ceramic Research Centre for XRD and XRF analysis, and to Mr. Naci SARAÇOĞLU from ATOMIKA Teknik Trade and Limited Company.

\section{REFERENCES}

[1] Ahmaruzzaman M. A review on the utilization of fly ash. Prog Energ and Combust 2010; 36: $327-$ 363.

[2] Collins RJ, Ciesielski SK. Highway construction use of wastes and by-products. In: Inyang HI, Bergeson KL, editors. Utilization of Waste Materials in Civil Engineering Construction. ASCE, NY, 1992, pp. 140.

[3] Sundum T, Szecsenyi KM, Kaewtatip K. Preparation and characterization of thermoplastic composites with ash modified by planetary ball milling. Carbohydr Polym 2018; 191: 198-204. 
[4] Patil AG, Anandhan S. Influence of planetary ball milling parameters on the mechano-chemical activation of fly ash, Powder Technol 2015; 281: 151-158.

[5] Dindi A, Quang DV, Vega LF, Nashef E, Abu-Zahra MRM. Applications of fly ash for CO2 capture, utilization, and storage. J CO2 Util 2019; 29: 82-102.

[6] Blissett RS, Rowson NA. A review of the multi-component utilization of coal fly ash. Fuel 97 2012; $1-23$.

[7] Feng W, Wan Z, Daniels J, Li Z, Xiao G, Yu J, Xu D, Guo H, Zhang D, May EF, Li G. Synthesis of high quality zeolites from coal fly ash: Mobility of hazardous elements and environmental applications. J Clean Prod 2018; 202: 390-400.

[8] Iyer RS, Scott JA, Power station fly ash-a review of value-added utilization outside of the construction industry. Resources, Conservation and Recycling 2001; 31: 217-228.

[9] Ojha K, Pradhan NC, Samanta AN. Zeolite from fly ash: synthesis and characterization. Bull Mater Sci 2004; 27(6): 555-564.

[10] Castellanos AG, Mawson H, Burke V, Prabhakar P. Fly-ash cenosphere/clay blended composites for impact resistant tiles, Constr Build Mater 2017; 156: 307-313.

[11] Yanga J, Huanga J, Sua Y, Hea XY, Tanb H, Yange W, Strnadel B. Eco-friendly treatment of lowcalcium coal fly ash for high pozzolanic reactivity: A step towards waste utilization in sustainable building material. J Clean Prod 2019; 238: 117962.

[12] Schwarz N, Neithalath N. Influence of a fine glass powder on cement hydration: comparison to fly ash and modeling the degree of hydration. Cement Concr Res 2008; 38 (4): 429-436.

[13] Yamamotoa T, Kanazua T, Nambub M, Tanosakic T. Pozzolanic reactivity of fly ash-API method and K-value. Fuel 85 2006: 2345-2351.

[14] Mezhov A, Pott U, Stephan D, Kovler K. Influence of mechanical activation of fly ash in presence of polynaphthalene sulfonate superplasticizer on rheology and hydration kinetics of cement - fly ash pastes. Constr Build Mater 2019; 210: 380-390.

[15] Rakngana W, Williamsona T, Ferrona RD, Santb G, Juenger MCG. Controlling workability in alkali-activated Class C fly ash. Construction and Building Materials 2018; 183: 226-233.

[16] Dakhanea A, Tweedleyb S, Kailasa S, Marzkec R, Neithalathd N. Mechanical and microstructural characterization of alkali sulfate activated high volume fly ash binders. Materials and Design 2017; 122: $236-246$.

[17] Marjanovića N, Komljenovića M, Baščarevića Z, Nikolić V. Comparison of two alkali-activated systems: mechanically activated fly ash and fly ash-blast furnace slag blends. In: 7th ScientificTechnical Conference Material Problems in Civil Engineering (MATBUD'2015); 2015; Procedia Engineering 108 ( 2015 ) 231-238

[18] Marjanovica N, Komljenovića M, Baščarevića Z, Nikolić V. Comparison of two alkali-activated systems: mechanically activated fly ash and fly ash-blast furnace slag blends. Procedia Engineering 
108 (2015) 231 - 238 7th Scientific-Technical Conference Material Problems in Civil Engineering (MATBUD’2015)

[19] Kumar R, Kumar S, Mehrotra SP. Towards sustainable solutions for fly ash through mechanical activation. Resour Conserv and Recy 2007; 52(2): 157-179.

[20] Rajak DK, Raj A, Guria C. Pathak AK. Grinding of Class-F fly ash using planetary ball mill: A simulation study to determine the breakage kinetics by direct- and back-calculation method. S Afr J Chem Eng 2017; 24: 135-147.

[21] Chindaprasirta P, Homwuttiwongb S, Sirivivatnanon V. Influence of fly ash fineness on strength, drying shrinkageand sulfate resistance of blended cement mortar. Cement Concr Res 2004; 34: 1087-1092.

[22] Lee SH, Kima HJ, Sakaib E, Daimon M. Effect of particle size distribution of fly ash-cement system on the fluidity of cement pastes. Cement Concr Res 2003; 33; 763-768.

[23] Turkish Statistical Institute, www.tuik.gov.tr

[24] ASTM C 618 (American society for testing and materials). Fly ash and raw or calcined natural pozzolan for use as, mineral admixture in portland cement concrete, Philadelphia, PA ASTM, 1997.

[25] Firat S, Yilmaz G, Comert AT, Sumer M, Utilization of marble dust, fly ash and waste sand (siltquartz) in road subbase filling materials. KSCE J Civ Eng 2012; 16(7): 1143-1151.

[26] Yilmaz G. Structural characterization of glass-ceramics made from fly ash containing $\mathrm{SiO}_{2}-\mathrm{Al}_{2} \mathrm{O}_{3}$ $\mathrm{Fe}_{2} \mathrm{O}_{3}-\mathrm{CaO}$ and analysis by FT-IR-XRD-SEM methods. J of Mol Struct 2012; 1019: 37-42.

[27] Wang T, Ishida T, Gu R. A comparison of the specific surface area of fly ash measured by image analysis with conventional methods. Constr Build Mater 2018; 190: 1163-1172.

[28] Sadique M, Al-Nageim H, Atherton W, Seton L, Dempster N. Mechano-chemical activation of high-Ca fly ash by cement free blending and gypsum aided grinding, Constr Build Mater 2013; 43: 480-489.

[29] Kato K, Xin Y, Hitomi T, Shiraia T. Surface modification of fly ash by mechano-chemical treatment. Ceram Int 2019; 45(1): 849-853.

[30] Fanghui H, Qiang W, Jingjing F. The differences among the roles of ground fly ash in the paste, mortar and concrete, Constr Build Mater 2015; 93: 172-179.

[31] Duan S, Liao H, Ma Z, Cheng F, Fang L, Gao H, Yang H. The relevance of ultrafine fly ash properties and mechanical properties in its fly ash-cement gelation blocks via static pressure forming. Constr Build Mater 2018; 186: 1064-1071.

[32] wrap-test.warwick.ac.uk

[33] Ersoy B, Kavas T, Evcin A, Baspınar S, Sarışık, A. Once G. The effect of BaCO3 addition on the sintering behavior of lignite coal fly ash, Fuel 87 2008; 2563-2571. 